\title{
Understanding The Relationship Among Leadership Effectiveness, Leader-Member Interactions And Organizational Citizenship Behaviour In Higher Institutions Of Learning In Ghana
}

\author{
Goski Alabi, Ph.D., Institute Of Professional Studies, Ghana
}

\begin{abstract}
The study ascertained the relationship between Quality of Leader-Member-Exchanges (QLMX) and Leadership Effectiveness (LE) with Organizational Citizenship Behaviour (OCB) as an intervening variable for $L E$ in public higher Institutions of learning in Ghana. The study was based on a quantitative cross-sectional design and a regression analysis within higher institutions of learning in Ghana. The results of the study show that there is a strong and positive relationship among the variables. Both LE and LMX had statistically significant influences on OCB at $1 \%$ respectively with coefficients of 1.2197 and 0.9534 respectively. LMX also had a statistically significant influence on LE at 1\% with a coefficient of 0.4255. Two of the four sub-scales of LMX - Affect and Professional had a statistically significant influence on LE at $1 \%$ and 5\% respectively. Three of the sub-scales of $L M X$ - affect, contribution, and professional respect - also had statistically significant influences on OCB three of the four sub-scales were significant at 5\%, $1 \%$ and $5 \%$ respectively. Worthy of note is the fact that for both LE and OCB loyalty was not found to have statistical influence. The study recommends that Leaders in HILs in Ghana should avoid cronyism, but rely more on modelling the way and encourage the heart to inspire commitment towards institutional vision in order to be effective.
\end{abstract}

Keywords: Leadership Effectiveness, LMX, OCB, Higher Institutions of Learning, Leader-Member-Exchanges, Organizational Citizenship

\section{INTRODUCTION}

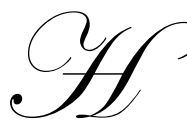

igher education plays a central role in shaping the quality of leadership in every society. However, in recent times the quality of output and effectiveness of HEIs have been brought to question. Many concerns have been raised concerning quality of output of higher education institutions. In the face of major challenges, like an increasing volume of applicants to HEIs, scarcity of resources, global economic turbulence, change, commoditization of higher education, and other key challenges, it is believed that the quality of higher education is undermined.

However, others believe that the distinctiveness of HEIs, the extraordinary amount of autonomy and professional discretion enjoyed by faculty, the ambiguity of purpose, goals and power, decision-making by compromise and bargaining, and the limits on administrators' formal authority makes the management of effectiveness quite a challenge unlike the corporate environment (Leveille 2006). Cameron as a result of the characteristics of the university environment and the people who work in it, gave HEIs a unique designation: "organized anarchies." Both Cameron (1980) and ONeill et.al (1999) argue that in an organized anarchy achieving and measuring effectiveness could be a challenging task. 
Astin and Astin (2000) and Shriberg (2005) argue that when quality of leadership in a higher education institution is poor, the quality of the graduates produced from these institutions of learning may also yield ambiguous results. Higher education institutions (HEIs) are required to demonstrate accountability and effectiveness like any other public organization. One major means of providing proof of effectiveness is by how graduates of HEIs contribute to development and value creation or common good of the society. Astin and Astin, (2000) further opine that students are not likely to commit themselves to making changes in society unless the institutions in which they have been trained displayed similar leadership commitments.

However, the volume of literature examining the role of leadership in the effectiveness of HEIs is surprisingly sparse. Dyer and Miller (1999) suggest that investigation of department chairs in HEIs in the US has tended to focus upon their roles and responsibilities, needed skills and challenges, and coping strategies and not on their effectiveness. Gomes and Knowles (1999), also state, "Although academic departments have been appointing heads for decades, little research exists concerning exactly how those leaders contribute to departmental culture, collaborative atmosphere, and departmental performance", (p. 81).) in (Bryman 2009). Harris et al. (2004) also add that, "While a few research studies have focused on leadership practices in higher education; little research has focused on leadership effectiveness or on the means for increasing effectiveness, particularly at the departmental level" (p. 4). Barge and Musambira (1992) also add, "Do chair-faculty relationships within academic institutions really make a difference for the department and the university?" While much of the leadership literature answers in the affirmative for non-academic organizations, this question has not been empirically tested in colleges and universities." (p. 75). This study therefore sought to ascertain some answers to this by investing the relationship among leadership effectiveness, leader member exchanges and organizational citizenship behaviour. It hypothesizes that if leadership affects organizational effectiveness than it shout relate to organizational citizenship behaviours.

\section{OBJECTIVES OF THE STUDY}

The key objective of the study is to ascertain the relationship among leadership effectiveness, leadermember exchanges and organizational citizenship behaviors (OCB). This study sought to measure LE using a construct developed from literature for this study. It also seeks to ascertain the level of OCB in HEIs and to relate this to LE. If leadership effectiveness can be measured from a perspective of the quality of interactions (LMX) then leader-member interactions should be a criterion variable for LE and OCB. The study seeks to find out the relationship among these three variables.

\section{THEORETICAL AND CONCEPTUAL FRAMEWORKS}

\section{The Contemporary Concept of Leadership}

Leadership is one of the most observed yet least understood phenomenons. Contemporary schools of leadership observe that the basic nature of leadership should be seen in terms of the interaction among the people involved in a process of achieving collective goals, which involves both leaders and followers. Brungardt \& Maughan (2005) conclude that leadership is a collaborative endeavour among group members and not the effort of a single individual. Brungardt \& Maughan (2005) emphasize that the essence of leadership is not the leader, but the relationship between the leader and follower. Contrary to definitions which have at their core the concept of influence and the fact that leaders influence others to help accomplish group or organizational objectives. Rost (1991) defines leadership as an influence of relationship among leaders and followers who intend real changes that reflect their mutual purposes and this definition is believed to be more consistent with contemporary organization.

In line with these views of leadership, the author opines that the new concept of leadership moves leadership from the notion of a personality based function to the concept of a process base interaction. In this case, the inputs into the leadership process are the leaders and followers, with the interactions being the transformational activity that translates into the influences which should produce commitment towards achievement of collective and individual goals. From this perspective, leadership becomes more horizontal as opposed to management which is more hierarchical. Consequently, the term 'followers' is substituted for by 'members' because both leaders and members negotiate for influence from each other. 
What this suggests is that the effectiveness of leadership would depend largely on the inputs of leadership which are (1) the nature of both the leader and the members (2) the interactions between the leader and members, which should yield commitment towards the goal achievement. Flowing from this premise, this study therefore posits that leadership effectiveness should relate to Leader-Member Exchanges that is the interactions between members and leaders and this can be accessed through the level of organizational citizenship behaviour as an output or indicator variable.

Brungardt \& Maughan. (2005), further notes that, this contemporary definition of leadership is composed of four basic components, each of which is essential and must be present if a particular relationship is to be called leadership. The first component is the fact that the relationship is based on influence. According to Rost (1993), this influence is multidirectional, meaning that influence can go anyway (not necessarily top-down), and the influence attempts must not be coercive. Therefore, the relationship is not based on authority, but rather persuasion. Secondly, Rost notes that both leaders and followers are the people in this relationship and therefore both leaders and followers do the leadership and all the players have influence though this influence is not equal. Thirdly, Rost argues that both leaders and followers intend real changes in the relationship where "'Intend means that the leaders and followers promote and purposefully seek changes, and "Real" means that the changes intended by the leaders and followers must be substantial. This reflects the mutual purposes of both leaders and followers. The key is that the desired changes must not only reflect the wishes of the leader but also the desires of the followers (Rost, 1993).

Crosby and Bryson (1999), in line with the views of Rost and Brungardt, characterize leadership as the inspiration and mobilization of others to undertake collective action in pursuit of the common good and therefore their framework was simply "leadership for the common good" Roach \& Behling, (1984). Long before, Rost, Brungardt, \& Maughan, (2005) and Crosby \& Bryson (1999) defined leadership as the process of influencing an organized group toward accomplishing its goals". Likewise, O'Niell (2003) also defines leadership as influencing people to get things done to a standard and quality above their norm and doing it willingly.

O'Neill further notes that as an element in social interaction, leadership is a complex activity involving a process of influence; actors who are both leaders and followers; a range of possible outcomes and not only the achievement of goals, but also the commitment of individuals to such goals and the enhancement of group cohesion and the reinforcement of change of organizational culture. This suggests that organizational citizenship behaviour, goal achievement, and challenging the process toward change would be good measures of leadership effectiveness.

Keith in Kouses \& Posner (2007, Pg.3) also adds to the contemporary view of leadership and states that, "Leadership is ultimately about creating a way for people to contribute to making something extraordinary happen." As Rost (1993) observes, leadership is not what leaders do; rather, leadership is what leaders and followers do together for collective good. Bryman (2009) notes that the concept of leadership as a form of collaboration or give and take interaction between leaders and followers is characteristic of the higher education environment where leadership is a shared-power interaction between leaders and members through the committee system of decision making. Thus contemporary leadership paradigm is characterized by collaboration, power-sharing facilitation, and empowerment.

Like Rost, three points about Keith's definition of leadership should be noted; first, leadership is a social influence process, which cannot exist without a leader and one or more followers. Secondly, leadership elicits voluntary action on the part of followers. The voluntary nature of compliance separates leadership from other types of influence based on formal authority. Finally, leadership results in followers' behaviour that is purposeful and goal-directed in some sort of organized setting. Despite this, the precise nature of leadership and its relationship to key criterion variables such as subordinate satisfaction, commitment, and performance is still uncertain. Almost all the reviews of leadership definitions and concepts follow that leadership process is a function of the leader, the follower, and the context where the context includes external, internal and change conditions.

For the purposes of this study, managerial leadership which is the central concept of leadership in this study is defined as a process by which people in positions of authority and members influence each other towards the attainment of group commitment to achieve organizational goals. 


\section{The Concept of Leadership in Higher Education}

Bolden (2008) argues that leadership is a relatively new concept within the higher education sector and is harder to define. Bolden reports that Hefce (2004) in setting out a strategic plan for the UK higher education sector, defined leadership as "Agreeing strategic direction in discussion with others and communicating this within the organisation; ensuring that there is the capability, capacity and resources to deliver planned strategic outcomes; and supporting and monitoring delivery. As such this definition embraces elements of governance and elements of management" (Hefce 2004, p35). Bolden further argues that such a definition, however, offers little insight into how leadership is actually enacted in higher education. Furthermore, it neglects the long and heated debate on the nature of leadership that makes it an 'essentially contested' concept which makes it more difficult to clearly conceptualize in education.

Filan and Seagren state that "the context of the higher education leadership mantle is dynamic, complex and multidimensional" (2003 p. 21). The elusiveness of the leadership notion has enticed researchers to interpret, capture and analyse the essence of leadership in higher education from different perspectives. Although these studies identified leadership as a concrete and observable phenomenon, no consensus has as yet been reached on the exact characteristics of a successful leader in higher education (Buller 2006, 159). The concept of leadership in higher education thus presents numerous opportunities for further investigation.

\section{Organizational Effectiveness versus Leadership Effectiveness}

There is a difference between organizational effectiveness and leadership effectiveness. Whereas organizational effectiveness deals with organizational output, in terms of effectiveness and/or efficiency, leadership effectiveness deals with the health of the organizational climate and the degree to which commitment is inspired towards shared values and goals (Scott \& Bruce (1994); Kouzes \& Posner, 2002; Wesse 1994).

Wesse (1994) maintains that effective leadership has a positive impact on behaviour within organizations. However, organizational effectiveness has impact on organizational output. With leadership effectiveness, leaders are capable not only to differentiate the results of their companies, but also can differentiate the satisfaction levels of the people working within these organizations (Wesse 1994).

According to Blanchard (2004), getting along with the boss a measure of leadership effectiveness is the number one factor that influences job happiness. Leadership effectiveness reflects how leaders and members perceive the importance of their own experiences with each other for organizational well-being, as well individual well being. Thus leadership effectiveness should translate into the organizational citizenship behaviour of the members.

\section{Organizational Citizenship Behaviour - Dependent Variable}

Organizational Citizenship Behaviour (OCB) was introduced by Smith, Organ and Near (1983, p. 4), and is defined as discretionary individual behaviour, not directly or explicitly recognized by the formal reward system, which, in the aggregate, promotes the effective functioning of the organization. Organizational Citizenship Behaviours (OCB) describes actions in which employees are willing to go above and beyond their prescribed role requirements. Prior theory suggests that these behaviours are correlated with indicators of organizational effectiveness (Yen \& Niehoff, 2004).

Organ (1988) and Schnake (1991) believe citizenship behaviours, although discretionary, are necessary because they promote effective functioning of the organization. In a study of 218 people working in a paper mill, Podsakoff et al. (1997) found a positive correlation between Citizenship Behaviour and the organization's output. Podsakoff et al. (1997) assert that Citizenship behaviour improves the effectiveness of the organization by the high degree of work group performance in terms of quantity and quality of work.

Lambert (2006) defined Organizational Citizenship Behaviour (OCB) as behaviour that goes beyond the basic requirements of the job and is to a large extent discretionary and on to the benefit to the organization" 
(Lambert, 2006, p. 503-525). According to Lambert, "OCBs are employee behaviours that, although not critical to the task or job, serve to facilitate organizational functioning".

Researchers maintain that the effective functioning of an organization depends on employee efforts that extend beyond formal role requirements of the job (Organ, 1988). Organ (1988) termed these extra efforts "organizational citizenship behaviours" (OCB), and defined them to include activities that target other individuals in the workplace (e.g., helping co-workers or communicating changes that affect others) and the organization itself (e.g., actively participating in group meetings or representing the organization positively to outsiders. Compliance behaviour, like note take extra breaks, punctuality, taking only the required lunch time, or not leaving early, working beyond normal time lines when required are also considered Organizational Citizenship behaviours. Lambert identified five categories of OCB: (1) altruism which entails the helping of an individual co-worker on a task, (2) courtesy, alerting others in the organization about changes that may affect their work, (3) conscientiousness, carrying out one's duties beyond the minimum requirements, (4) sportsmanship, refraining from complaining about trivial matters, and (5) civic virtue, participating in the governance of the organization.

More recent conceptualizations of OCB offer slightly different categorizations. For example, Podsakoff and MacKenzie (1994) combined aspects of altruism and courtesy and termed it "helping." Two main facets of OCB are mentioned in previous studies are OCB altruistic, and OCB compliance (Smith et. al, 1983). Whereas altruism appears to represent the help to specific persons, generalized compliance is a factor defined by a more impersonal sort of conscientiousness. It implies more of a "good soldier" or "good citizen" syndrome of doing things that are "right and proper", but doing them for the sake of the system rather than for specific persons. In the view of Smith et al. (1983), the two elements represent distinct classes of citizenship behaviours.

Management literature suggests that dealing with citizenship has a political perspective. The political aspect of citizenship consists of three elements obedience; loyalty, and participation (Organ 1988). A few studies have shown that OCB are positively related to indicators of individual, unit, and organizational performance (Podsakoff, Ahearne, \& MacKenzie, 1997; Walz \& Niehoff, 2000; Werner, 1994).

Empirical evidence on the relationship among OCB LMX and Organizational effectiveness Truckenbrodt (2003) reports that a significant relationship exist between quality of leader member exchanges and commitment, and altruistic organizational citizenship behaviour of members; which according to LMX theory, aims at organizational success.

\section{Conceptual Framework}

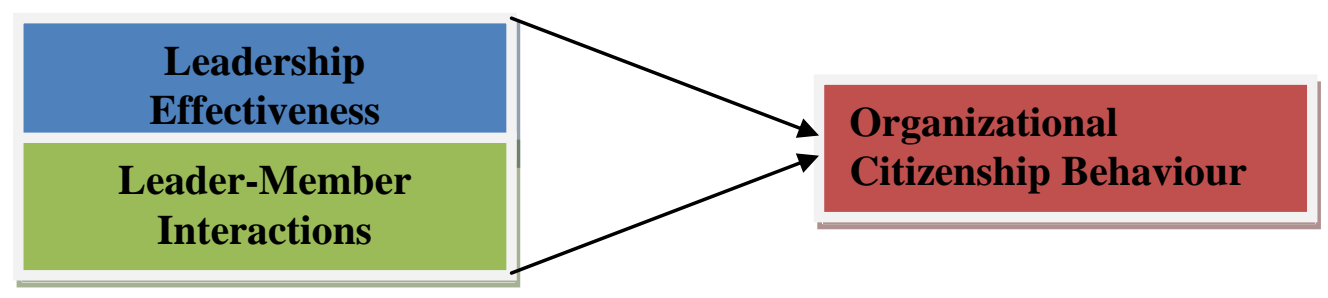

Figure 1. Conceptual Framework of the Relationship between the Variables

\section{Operational Definitions and Constructs}

In this study, leadership effectiveness (Dependent Variable) is defined as the ability to inspire commitment towards organizational mission and goals; and to navigate challenges, solve problems and mobilize resources for the purposes of inspiring change. LE is operationalized by a combination of the leadership practices inventory (LPI) by Kouse and Posner (2002) and the Adversity Quotient Profile (AQP) measuring Leadership Resilience by Stoltz, (2009). The LPI has five indicators are inspiring a shared vision, modelling the way, challenging the process, encouraging the heart, and enabling others to act. 
Quality of Leader-Member Exchanges (the independent variable) is defined as quality defined as 'quality of the working relationship between leaders and faculty members. It is operationalized by LMX-MDM, a twelve item instrument with four indicators with each indicator having three items under it and these are - affect, loyalty, contribution, and professional respect.

Organizational citizenship behaviour (OCB), is defined as behaviour that (a) goes beyond the basic requirements of the job, (b) is to a large extent discretionary, and (c) is of benefit to the organization" (Lambert, S.J., 2006, p. 503-525) and is operationalized by the OCB - Scale by Smith et. al, (1983).

Higher Institution of Learning is a constructed as World Bank definition of HILs which considers HILs as degree-granting tertiary institutions.

\section{RESEARCH QUESTIONS AND HYPOTHESES}

R1: What is the relationship between Organizational Citizenship Behaviour and Leadership Effectiveness in Higher Institutions of Learning in Ghana?

H1 : Members organizational Citizenship Behaviours have no relationship with leadership effectiveness in higher institutions of learning in Ghana

H1 $_{\mathbf{a}}$ : Members organizational Citizenship Behaviours have a relationship with

R2: Does leader-member interaction have a relationship with members' citizenship behaviour in higher institutions of learning in Ghana?

$\mathbf{H 2}_{\mathbf{0}}$ : A leader's interaction with members has no effect on members' commitment in higher institutions of learning in Ghana

H2 2 : A leader's interaction with members has an effect on members' commitment in higher institutions of learning in Ghana.

\section{METHODOLOGY}

\section{Research Design}

This study employs a correlational and cross-sectional survey designs to investigate the relationship between Organizational Citizenship behaviour and Leader-Member-Exchanges (LMX) and Leadership Effectiveness (LE). It uses quantitative techniques, specifically basic statistical techniques to achieve its stated objectives. OCB is the Dependent variable whereas LMX and LE are the independent variables. Data was collected from a number of leaders which included Heads of Departments, Deans, Rectors and Vice Chancellors of six (6) Higher Institutions of Learning in Ghana, purposively selected.

\section{Population and Sample}

The population for the study was made up of staff from six public degree-awarding Institutions of Learning in Ghana. The sample consisted of a target of 600 full-time administrative staff and academic staff proportionately drawn from the institutions. The Institutions were purposively selected. The sample was drawn randomly from the list (sampling frame) of administrative staff and lecturers from each selected public institution. The selected institutions included Ghana Institute of Management and Public Administration (GIMPA) Accra, University of Ghana (UoG), the University of Cape Coast- CapeCoast, University of education,- Winneba, Kwame Nkrumah University of Science and Technology (KNUST)- Kumasi and Institute of Professional Studies, Accra. The institutions were purposively selected. The choice of these institutions was informed by the fact that they individually possess unique features that are representative of all public higher institutions of learning in Ghana. University of Ghana is the oldest and largest institution in Ghana; KNUST is the largest public university in Ghana providing pure science related degree programmes. GIMPA traditionally is a specialised institution providing training in short competence based courses and degrees in public administration and business management although it is public, it does not rely on government subvention and determines its own salary structure. IPS started as an institution providing education in professional programs related to business administration/management. IPS is the youngest public institution, as at 2010 mandated to award degrees, and has been running degree programmes for about six years now. 
Institutions for the study were purposively selected taking into consideration the prorgarmmes offered, location and size. Convenient sampling procedure was then used in selecting respondents. This choice was informed by the fact that the selected institutions were unable to provide the sampling frame (the list of lecturers, administrators and deans) for the study. The time available for this research made it impossible to develop a new sampling frame. Five (5) enumerators used for the data collection, selected any faculty member or administrator or person on first contact in the various faculties, colleges and departments at random and any other person who falls within the sample frame and was available and willing to participate in the research (Creswell, 2009).

\section{Data Collection}

The services of five enumerators were sought in the data collection process. To achieve high response rate and reliability, a researcher administered survey method was used in administering the survey instruments. Five (5) research assistants at the School of Research and Graduate Studies of the Institute of Professional Studies were selected as enumerators and trained on the administration of the questionnaire. The trained enumerators were also involved in piloting the instruments to ensure that they were very familiar with the instruments and to ensure that the exact responses were elicited. The five enumerators administered the questionnaires in all six (6) selected public universities including University of Ghana, Cape-Coast University, University of Education Wineba and two (2) Degree awarding specialized Institutions: Ghana Institute of Management and Public Administration (GIMPA) and Institute of Professional Studies (IPS). The instruments were given to Deans of schools, heads of department, faculty members and administrators.

\section{Instruments of Data Gathering}

Measuring the Quality of LMX - The Independent Variable

Many different questionnaires have been used by researchers to study LMX theory. All of them have been designed to measure the quality of the working relationship between leaders and followers. Though the LMX 7, a seven-item questionnaire is reported to provide a reliable and valid measure of the quality of leadermember exchanges, it has been criticized for it uni-dimensionality (Dionne et al.2000, Labo 2005). The LMX 7 is designed to measure three dimensions of leader-member relationships: respect, trust, and obligation. It assesses the degree to which leaders and followers have mutual respect for each other's capabilities, feel a deepening sense of reciprocal trust, and have a strong sense of obligation to each other. Taken together, these dimensions are believed to be key ingredients necessary to create strong partnerships.

As a result of the critiques of LMX-7 this study sought to adopt the LMX - MDM scale first developed and used by Dienesch and Liden (1986). The LMX-MDM has twelve items on a 7 point Likert scale. The tool has four categories each comprising three items. These categories are: Affect, Loyalty, Contribution and Professional Respect.The difference with the unidimensional scale is that there are now four dimensions to compare the variables with, whether there is job satisfaction, LE, OCB or any other variable to be compared with. This allows the researcher to go another step in analyzing LMX because each category can then better explain the findings.

\section{Multidimensionality of LMX}

Dienesch and Liden (1986 p 625) suggest that LMXs may be based on varying amounts of three currencies of exchange. Task related behaviours (labeled contribution), loyalty to each other (labeled loyalty), and simply liking one another (labeled affect) (Dionne (2000). Dionne further notes that, "These three dimensions act as "currencies of exchange" which both parties in an LMX can bring to the relationship." Dionne (2000) argues that these dimensions are not the only ones that could be hypothesized (Gergen, Greenberg, \& Willis, 1980) and so added a fourth dimension which is professional respect. However, these are grounded in an established concept (mutuality) and invoke constructs (i.e., loyalty and affect) that have been extensively researched. Therefore, these dimensions provide a good starting point for empirical research on the dimensionality issue" (Dionne 2000). 
The Leader-Member Exchange (multi-dimensional) LMX-MDM scale, from Liden \& Maslyn, 1998) has 12 items. The questionnaire uses a Likert-like scale that ranges from 1 to 7 . There are also 4 sections in the questionnaire which reflect four dimensions of LMX. These four dimensions are Affect (Q1, Q2, Q3), Loyalty (Q4, Q5, Q6), Contribution (Q7, Q8, Q9), and Professional respect (Q10, Q11, Q12). Total LMX is represented by questions 1 to 12 .

\section{Reliability of the LMX-MDM Scale}

Each of the four categories of the LMX-MDM was tested for reliability from the Cronbach Alpha by Liden \& Maslyn, (1998). The results were as follows: Affect .92, Loyalty .85, Contribution .76 and Professional respect .94. The alpha for Total LMX is .92.

According to McMillan \& Schumacher (1997), the reliability coefficient is a correlation statistic comparing two sets of scores from the same individuals. The scale for reliability coefficient is from .00 to .99 . If the coefficient is high, for example: 90 , the instrument has little error and is highly reliable. The opposite is true for the correlation near .20 or .35 . An acceptable range of reliability for coefficients for most instruments is .70 to .90 . This suggests that taken together a total reliability score of 0.92 make it a reliable instrument for the study.

\section{Validity of the LMX-MDM Scale}

Validity of the LMX-MDM may be derived from support for the 4-factor model using exploratory factor analysis and confirmation using CFA with independent samples (Bagozzi, Yi, \& Phillips, 1991). However, consistent with Schmitt and Klimoski's (1991) argument that validity is best assessed using multiple approaches, Liden \& Maslyn, (1998) examined the scale with respect to response bias susceptibility, convergent validity, discriminate validity, and criterion-related validity and concluded that the scale was valid.

\section{Measuring Leadership Effectiveness - The Independent Variable}

The instrument constructed for measuring leadership effectiveness has three (3) sub-scales: the first component sought to obtain data on respondents' demographic profile; the second contain 30 items on leadership Practices Inventory and 10 items relating to Adversity Quotient.

The instrument was self developed but with adapted components. Aside the items under participant demographic data, there were 40 items on a seven point Likert scale drawn from two sources based on the Leadership Practices Inventory (LPI) 30 items by Kouzes and Posner (2002) and Adversity Quotient Profile 10 items adapted from Stoltz (2009) version 8.1 provided online.

The 30 items in the LPI fall under five indicators each made up of six (6) items. The five indicators of the LPI are Inspiring a Shared Vision, Challenging the Process, Enabling Others to Act, Modeling the Way, and Encouraging the Heart;

The LPI is a questionnaire with thirty behavioural statements six for each of The Five Practices, that takes 10 to 20 minutes to complete. Leaders complete the LPI-Self, rating them on the frequency with which they think they engage in each of the thirty behaviours. Five to ten other people typically selected by the leaders-complete the LPI-Observer questionnaire, rating the leaders on the frequency with which they think they engage in each behaviour. Respondents can indicate their relationship to the leader who may be a manager, co-worker or peer, direct report, or other observer but, with the exception of the leader's manager, all the observers' feedback is anonymous. 


\section{Reliability of the LPI}

Reliability of the LPI has been routinely tested through analysis of internal reliability, and all five leadership practices have consistently shown strong internal reliability coefficients. This means that the items are highly correlated within each scale. Test and retest reliability is also high. Overall, the LPI has been extensively applied in many organizational settings and is highly regarded in both the academic and practitioner world. The reliability of the LPI has been established through extensive researched and therefore it was considered as reliable and valid measures for this study, though re-reliability test were performed on it.

\section{Measuring Organizational Citizenship Behaviour - The Dependent Variable}

The Organizational Citizenship Behaviour (OCB) construct was also used to ascertain members' citizenship behaviours as a proxy variable for members' level of commitment to organizational goals which was assumed to reflect leadership effectiveness. This instrument introduces items to test the level of extra effort and compliance of members to behaviours that are not formally recognized or rewarded by the formal system.

The organizational citizenship Behaviour (OCB) scale is a 16 items instrument developed by Smith et. al (1983). All the measures were constructed with closed ended questions with a Likert type scale. It is also based on subordinates self report. It is a five-point Likert scale containing the following anchors: from (1) strongly Dissaggree to (7) strongly agree.

The OCB has two subscales. The first is altruism (6-item) (e.g., helps others who have been absent; volunteers for things that are not required; orients new people even though it is not required; helps others who have heavy workloads). The second is compliance ( 8 item)measuring general compliance (e.g., punctuality; attendance at work is above the norm; gives advance notice if unable to come to work; does not take extra breaks; does not spend time in idle conversations), (Smith et al., 1983).

\section{Reliability and Validity test for Combined Instruments with Components}

Even though all the instruments adapted for the study have been used in previous studies and have been proven to be reliable and valid, the study re-tested for reliability and validity for the composite instrument. Reliability was ascertained by administering the entire instrument with the various constructs to the same group (30 people) twice with one week interval. The results for the internal consistency test of the constructs are found in Table 1 with alpha values ranging between 0.9233 and 0.956 ). The results show that all the constructs have reliable scales with good internal consistencies.

Construct validity was tested using two different groups of 20 people. The correlation coefficients ranging between 0.7799 and 0.9715 show that the various constructs are valid for the purposes of the aims of the study.

\section{Data Analysis}

This study adopts a quantitative procedure to investigate the relationship between Leadership effectiveness on one hand and Leader-Member-Exchanges and organizational citizenship behaviour on the other, controlling for demographic characteristics. The test of hypothesis was set at a significance level of 1,5 and $10 \%$.

\section{Model specification}

This study models the relationship between leadership effectiveness and a vector of determinant. The broad formulation of the statistic model is shown in equation 1.

$$
y_{i}=x_{i}^{\prime} \beta+\varepsilon_{i} \quad i=1,2, \ldots N
$$

Where $y_{i}$ represents the observed dependent variable for individual (respondent) $i ; x$ is a vector of control covariates that explain variations in the dependent variable and $\varepsilon$ is the idiosyncratic or stochastic error term. 
In this study we model LE as a function of LPI, AQ, LMX with OCB as an intervening variable and some control variables as follows:

$$
\begin{aligned}
& L E_{i}=\beta_{0}+\beta_{1} \text { Age }_{i}+\beta_{2} \text { Gender }_{i}+\beta_{3} E d u_{i}+\beta_{4} L M X_{i}+\beta_{5} L P I_{i}+\beta_{6} A Q_{i}+\varepsilon_{i} \\
& O C B_{i}=\delta_{0}+\delta_{1} L E_{i}+\delta_{2} L M X_{i}+\mu_{i}
\end{aligned}
$$

Where LE is a categorical variable with 1 representing strongly disagree and 7 representing strongly agree to leadership Effectiveness indicators.

$$
L E_{i}= \begin{cases}1 & \text { StronglyDisagree } \\ 2 & \text { Disagree } \\ 3 & \text { Disagree Somewhat } \\ 4 & \text { Neutral } \\ 5 & \text { Disagree Somewhat } \\ 6 & \text { Agree } \\ 7 & \text { Strongly Agree }\end{cases}
$$

LMX represents Leader-Member-Exchanges and Organizational Citizenship Behaviours (OCB) measures the health of the organizational climate and commitment of members to organizational goals. The principal objective is to assess the extent to which variations in LMX and LE explain changes in OCB in higher institutions of learning in Ghana. The control variables include respondents' age, gender, and educational status. $\beta$ is a vector of coefficients and $\varepsilon$ is the random error term.

\section{Estimation procedure}

Traditional Ordinary Least Squares (OLS) is inappropriate to estimate equation (2) if the dependent variable is categorical (Wooldridge, 2002 \& Greene, 2002, 2005). Using OLS may result in inefficient estimates of the parameters because the error structure is heteroskedastic and sometimes serially correlated. The most appropriate model for the estimation of this model is Ordered Logit and Ordered Probit models, Wooldridge, (2002). Ordered Logit or Probit models are used when the dependent variable is categorical and ordered.

Let $y_{i}$ be an ordered response taking on the values $\{1,2,3,4,5,6$ and 7$\}$ with description as follows:

$$
y_{i}= \begin{cases}1 & \text { StronglyDisagree } \\ 2 & \text { Disagree } \\ 3 & \text { Disagree Somewhat } \\ 4 & \text { Neutral } \\ 5 & \text { Disagree Somewhat } \\ 6 & \text { Agree } \\ 7 & \text { Strongly Agree }\end{cases}
$$

When the response variable is ordered, OLS residuals are heteroskedastic and serially correlated. The appropriate choice is the ordered Logit or ordered Probit models (see Cameron and Trivedi (2002). The choice 
between the ordered logit and probit is based on the assumption of the residual $\varepsilon$. Ordered Probit model for $y$ conditioned on $\mathrm{x}$ is derived from a latent model with the latent variable $\mathrm{y}^{*}$. Assume the latent variable is determined by

$$
y^{*}=x \beta+\varepsilon \quad \varepsilon \mid x \sim \operatorname{Normal}(0,1)
$$

Let $\alpha_{1}<\alpha_{2}<\alpha_{3}<\alpha_{4}<\alpha_{5}$ be the unknown cut points (or the threshold parameters) and define

$$
y_{i}= \begin{cases}1 & \text { if } y^{*} \leq \alpha_{1} \\ 2 & \text { if } \alpha<y^{*} \leq \alpha_{2} \\ 3 & \text { if } \alpha_{2}<y^{*} \leq \alpha_{3} \\ 4 & \text { if } \alpha_{3}<y^{*} \leq \alpha_{4} \\ 5 & \text { if } \alpha_{4}<y^{*} \leq \alpha_{5}\end{cases}
$$

The parameters $\alpha$ and $\beta$ can be estimated by maximum likelihood estimator. The log likelihood for each $\mathrm{i}$ (cross sectional unit) is given by:

$$
\begin{aligned}
l_{i}(\alpha, \beta)= & 1\left[y_{i}=0\right] \log \left[\phi\left(\alpha_{1}-x_{i} \beta\right)\right]+1\left[y_{i}=1\right] \log \left[\phi\left(\alpha_{2}-x \beta\right)-\phi\left(\alpha_{1}-x_{i} \beta\right)\right] \\
& +\ldots+1\left[y_{i}=5\right] \log \left[\phi\left(1-\phi\left(\alpha_{5}-x_{i} \beta\right)\right]\right.
\end{aligned}
$$

Replacing the Logit Function $(\phi)$ with the Probit function $(\wedge)$ gives the ordered Logit model. The choice between the ordered Logit and Probit is based on the assumption about the error term. The Probit regression assumes a normal distribution whiles the Logit regression assumes a Logistic distribution. The main difference between the logistic cumulative distribution function (CDF) and the normal CDF is that the former has slightly fatter tails (there is more mass in the tails of the distribution than that in the normal distribution). Key challenges of interpreting the logit and probit outcomes has to do with the fatter tails of the logistic distribution (logit) than probit that might give quite different values that are difficult to interpret (Amemiya 1981).

The study employed probit and logist regression models because the data set is categorical and therefore ordinary least squares (OLS) would not be appropriate, because the error term is heterostiodastic .

\section{RESULTS}

The study found specific dimensions that relate to leadership effectiveness in higher institutions of learning in Ghana. Some specific variable were not statistically significant. The regression analysis revealed the following equation:

$$
\begin{aligned}
& \mathrm{LE}=13.542-0.009(\mathrm{Age})+0.096(\text { Gender })+0.426(\mathrm{LMX})+4.714(\mathrm{LPI})+0.531(\mathrm{AQ}) \\
& \begin{array}{llllll}
\mathrm{p} \leq 0 & 0.000 & 0.899 & 0.000 & 0.000 & 0.000
\end{array} \\
& \text { OCBí }=1.6113+1.2197 \mathrm{LE}+0.9534 \mathrm{LMX}+\text { ui } \ldots \ldots \ldots \ldots \ldots \ldots \ldots \\
& \begin{array}{lll}
\mathrm{P} \leq 0 & 0.000 \quad 0.000
\end{array}
\end{aligned}
$$


Table 1: Non Linear Regression of Relationship between Leadership Effectiveness, Organizational Citizenship Behaviour and A Vector of Covariates

\begin{tabular}{|c|c|c|c|c|c|}
\hline & (1) & (2) & (3) & (4) & (5) \\
\hline & LE & LE & OCB & OCB & OCB \\
\hline \multirow[t]{2}{*}{ Age of Respondents } & -0.0088 & 0.0065 & & & \\
\hline & $(-0.40)$ & $(0.27)$ & & & \\
\hline Gender of Respondents & 0.0957 & -0.3105 & & & \\
\hline \multirow{2}{*}{$\begin{array}{l}\text { Leader-Member-Exchanges } \\
\text { (LMX) }\end{array}$} & $0.4255^{*}$ & -0.1115 & & $0.9534^{* * * *}$ & \\
\hline & $(1.81)$ & $(-0.20)$ & & $(7.05)$ & \\
\hline \multirow[t]{2}{*}{ Adversity Quotient (AQ) } & $0.5308^{* * * *}$ & 0.3413 & & & \\
\hline & $(2.72)$ & $(1.50)$ & & & \\
\hline \multirow[t]{2}{*}{ Leadership Practices Inventory } & $4.7142^{* * * *}$ & $3.6242^{* * * *}$ & & & \\
\hline & $(11.76)$ & $(5.66)$ & & & \\
\hline \multirow[t]{2}{*}{$\begin{array}{l}\text { Leader-Member-Exchanges } \\
\text { (Affect) }\end{array}$} & & $0.7962^{* * * *}$ & & & $0.2574^{* * *}$ \\
\hline & & $(3.04)$ & & & $(2.13)$ \\
\hline \multirow[t]{2}{*}{$\begin{array}{l}\text { Leader-Member-Exchanges } \\
\text { (Loyalty) }\end{array}$} & & -0.2330 & & & 0.0849 \\
\hline & & $(-1.01)$ & & & $(0.84)$ \\
\hline \multirow[t]{2}{*}{$\begin{array}{l}\text { Leader-Member-Exchanges } \\
\text { (Contribution) }\end{array}$} & & -0.0975 & & & $0.3837^{* * * *}$ \\
\hline & & $(-0.38)$ & & & $(3.22)$ \\
\hline \multirow[t]{2}{*}{$\begin{array}{l}\text { Leader-Member-Exchanges } \\
\text { (Professional Respect) }\end{array}$} & & 0.0001 & & & $0.2941^{\text {*** }}$ \\
\hline & & $(0.00)$ & & & $(2.53)$ \\
\hline \multirow[t]{2}{*}{ Leadership Effectiveness } & & & $1.2197^{* * * *}$ & $0.7194^{* * * *}$ & $0.7047^{* * * *}$ \\
\hline & & & $(11.03)$ & $(5.50)$ & $(5.07)$ \\
\hline \multirow[t]{2}{*}{ cut1: Constant } & $13.5422^{* * * *}$ & $16.0840^{* * * *}$ & 0.1205 & $1.6113^{*}$ & $1.8549^{* * *}$ \\
\hline & $(7.95)$ & $(7.20)$ & $(0.15)$ & $(1.85)$ & $(2.09)$ \\
\hline Observations & 228 & 228 & 337 & 337 & 337 \\
\hline Log lik. & -109.1969 & -94.7543 & -427.672 & -401.5084 & -398.3676 \\
\hline Chi-squared & 466.5882 & 495.4733 & 144.2083 & 196.5375 & 202.8191 \\
\hline p-values of chi2 & 0.0000 & 0.0000 & 0.0000 & 0.0000 & 0.0000 \\
\hline
\end{tabular}

The analysis found evidence of a positive relationship among LE and organizational citizenship behaviours, LMX and Organizational Citizenship Behaviour and LE and LMX. However, Loyalty did not have a statistically significant influence on both Leadership Effectiveness and Organizational Citizenship Behaviour.

\section{Hypothesis 1}

R1: What is the relationship between Organizational Citizenship Behaviour and Leadership Effectiveness in Higher Institutions of Learning in Ghana?

H1 : Members organizational Citizenship Behaviours have no relationship with leadership effectiveness in higher institutions of learning in Ghana

H1 $1_{\mathbf{a}}$ : Members Organizational Citizenship Behaviours have a relationship with leadership effectiveness in higher institutions of learning in Ghana.

The study finally tests the relationship between leadership effectiveness and organizational citizenship behaviour in higher institutions of learning. Regression in last two columns reports the coefficients of Leadership effectiveness and LMX. A positive and statistically significant relationship is observed between LE and OCB; and LMX and OCB. This implies that null hypotheses 1 and 2 are rejected at 5\% respectively. The results is inline with assertion of Weese (1996) and Lim and Cromartie (2001), Lim and Cromartie, (2001); Weese, (1996), who recognized that a significant relationship exists between transformational leadership and organizational culture. 
According to them the distinguishing attributes of leadership effectiveness therefore could be summarized by Organizational Citizenship Behaviours which measures degree of commitment (altruistic behaviours and compliance behaviours), loyalty and preparedness to sacrifice towards the achievement of common goal and share $\mathrm{d}$ values is the result of leadership effectiveness in higher institution of learning. From the result of the study, OCB can be used as a proxy variable for leadership effectiveness.

\section{Hypothesis 2}

R2: Does leader-member interaction have a relationship with members' Organizational Citizenship Behaviour in higher institutions of learning in Ghana?

H2: Quality of leader- member exchanges has no effect on members' Organizational Citizenship Behaviour in higher institutions of learning in Ghana

$\mathbf{H 2}_{\mathbf{a}}$ : Quality of Leader member exchanges has an effect on members' Organizational Citizenship Behaviours in higher institutions of learning in Ghana.

The statistic estimate of QLMX on Organisational Citizenship Behaviour shows a positive and statistically significant influence at $1 \%$ (see hypothesis 6). On organizational Citizenship behaviours, three of the four components of LMX have significant relationships with OCB. The coefficients of affect, contribution and professional respect are positive and statistically significant at 5\%,1\% and 5\% respectively. The coefficient of loyalty is not statistically significant. This result suggest that affection between the leader and members, contribution and the existence of professional respect are important contributory factors to achieving organizational citizenship behaviour in HILs. The result suggests that improved quality of interaction between the leader and subordinates (affection, respect and contribution) among others will in the long run enhance commitment, and high output performance among subordinates. This result is consistent with the findings of Truckenbrodt's (2003), study, which for instance, reports that a significant relationship exists between the quality of leader member exchanges, commitment, and altruistic organizational citizenship behaviour of members; which according to LMX theory, aims at organizational success. The statistically significant impact of QLMX implies rejection of H20.

\section{CONCLUSION AND RECOMMENDATIONS}

This research sought to ascertain the relationship between leadership effectiveness organizational citizenship behaviour and LMX in higher institutions of learning in Ghana. The study assumed that organizational citizenship behaviour was explained by two principal factors: leadership effectiveness and the quality of leadermember-exchanges in higher institutions of learning. Leadership effectiveness was also a function of three (3) broad indicators including quality of leader-member-exchanges, leadership practices inventory and adversity quotient; the latter served as a proxy for leader's resilience (Dionne, 2000; Truckenbrodt, 2003).

The study first performed a Probistic regression of leadership effectiveness on the composite quality of leader-member-exchanges. Next, is a regression of organizational citizenship behaviour on leadership effectiveness and quality of leader-member-exchanges and the fourth, a regression of organizational citizenship behaviour on leadership effectiveness and the components of quality of leader-member-exchanges.

R2: Is leader-member interaction related to with members' citizenship behaviour in higher institutions of learning in Ghana?

Quality of leader member exchanges (QLMX) shows a positive and statistically significant influence on organisational citizenship behaviour at $1 \%$. Three of the four components of QLMX Affect, Contribution and Professional Respect have statistically significant relationships with OCB statistically significant at 5\%, $1 \%$ and 5\% respectively. The coefficient of loyalty is not statistically significant even at $10 \%$. This result suggests that loyalty does not influence members' organizational citizenship behaviours either in form of extra effort or compliance in higher institutions of learning in Ghana.

R1: What is the relationship between organizational citizenship behaviour and leadership effectiveness in higher institutions of learning in Ghana? 
The result further showed that leadership efectiveness had positive and statistically significant influence on organizational citizenship behaviour. In conclusion, the study found similarities with Wang, Law \& Hacket (2005), observation which showed that leader-member exchange fully mediated between transformational leadership and task performance as well as organizational citizenship behaviours. The implications of the study are that leaders in HILs in Ghana can enhance leadership effectiveness by paying attention to interactions with members and professional respect for themselves and members.

\section{LIMITATIONS}

One major factor that limits this study is the inability to introduce constructs of organizational characteristics into the Leadership effectiveness model (size, age, area of focus). Additionally, the impact of LMX and LE on OCB may vary across the various components of OCB, that is the altruisms and compliance subscales. This gives an opportunity for further to examine the impact on the subscales. Further studies on the relationship among the key variables in this study must be considered over time in a longitudinal design using a fully-articulated model.

\section{AUTHOR INFORMATION}

Dr. Goski Alabi is a Senior Lecturer in Management and Dean, School of Research and Graduate Studies Institute of Professional Studies, Ghana. She received her Doctor of Business Administration (DBA) from the Swiss Management Centre University and a consultant in Total Quality Management. Goski is also a Chartered Quality Professional of the Chartered Quality Institute (UK) with (CQP, MCQI). Goski is a Quality Management Consultant and was the Lead Facilitator for the National Quality Awareness Workshops in Ghana, consulting for the Ministry of Trade and Industry. She is also a framework consultant and certified Member of the Europe - Africa- Caribbean Liaison Committee (COLEACP) Inter Professional Association on the Pesticides Initiative Program (PIP) as a Service Provider for Good Company Practices working with Fruits and Vegetable exporters in Ghana. E-mail: goskia@yahoo.com

\section{REFERENCES}

1. Abbot, A.T., (2009). The General Agreement on Trade in Services (GATS). Educate Vol. 9. No.2.:7-17

2. $\quad$ Astin A.W., \& Astin H.S., (2000). Leadership Reconsidered: Engaging Higher Education in Social Change.Battle Creek MI, W.K. Kellogg Foundation.

3. Barge, J.K. \& Musambira, G.W. (1992). Turning Points in Chair-Faculty Relationships. Journal of Applied Communication, 20: 54-77.

4. Bolden R., Petrov. G., Gosling J., (2008), Developing Collect Leadership in Higher Education, Leadership Foundation for Higher Education, London UK.

5. Bryman , A. (2009). Effective Leadership In Higher Institutions. The Leadership Foundation for Higher Education.

6. Brungardt, C.L. \& Maughan, M. (2005). Understanding Leadership: Theories and ... www.utexas.edu. pipl.com/directory/name/Brungardt/180 - United States

7. $\quad$ Buller 2006

8. Cameron, K. (1986). A study of Organizational Effectiveness and its Predictors. Management Science, 32, 87-112.

9. Cameron, K. S., (1980) Critical Questions in Assessing Organizational Effectiveness, Journal of Organizational Dynamics 3: 0

10. Campbell, J., McCloy, R., Oppler, S., \& Sager, C. (1993). A theory of performance. In N. Schmitt \& W. Borman (Eds.), Personnel Selection in organizations (pp. 35-71). San Francisco: Jossey-Bass.

11. Creswell, J. W. (2009). Research design: Qualitative, quantitative, and mixed methods approaches. Thousand Oaks, CA: Sage publications.

12. Cronbach, L. J. (1984). Essentials of psychological testing (4th ed.). San Francisco: Harper \& Row.

13. Crosby, L. A., Evans, K. R., \& Cowles, D. (1990), Relationship quality in services selling: An interpersonal influence perspective. Journal of Marketing, 54(July): 68-81. 
14. Dionne L., ( 2000), Leader-Member Exchange (LMX): Level of Negotiating Latitude and Job Satisfaction, Research Report, Université De Moncton, Shippagan, 218 Boul. Gauthier,

15. Dienesch, R.M., Liden, R.C. (1986). Leader-member exchange model of leadership: A critique and further development. Academy of Management Review, 11: 618 -- 634.

16. Dyer, B.G. and Miller, M. (1999). A Critical Review of Literature Related to the Department Chair Position. ERIC. Retrieved from http://eric.ed.gov/ERICDocs/data/ericdocs2/content_storage_01/0000000b/80/11/97/28.pdf

17. Filan, G.L. \&Seagren, A.T, (2003), Academic Leadership: A Practical Guide to Chairing the Department, participative management academic leadership journal, Pg.21

18. Gomes, R. and Knowles, P.A. (1999). Marketing Department Leadership: An Analysis of a Team Transformation. Journal of Marketing Education, 21, 164-174.

19. Greenberg, Jerald, and Robert A. Baron (2000). Behavior in Organizations: Understanding and Managing the Human Side of Work. Upper Saddle River, NJ: Prentice-Hall.

20. Green, F. (1988). Leaders for a New Era: Strategies for Higher Education. New York: Macmillan.

21. Harris, J., Martin, B.N. and Agnew, W. (2004). The Characteristics, Behaviours, and Training of Effective Educational/Leadership Chairs. In Thompson, D.C. and Crampton, F.E. (eds.), The Changing Face(s) of Educational Leadership: UCEA at the Crossroads. Kansas City, Missouri, PUB. Team Performance Management, 3(4), 270-287.

22. Harris, A. (2003). Teacher Leadership as Distributed Leadership: Heresy, Fantasy or Possibility? School Leadership and Management 23(3), 313-324.

23. Hefce 2004, Hefce Strategic Plan 2003-2008, Revised April 2004, Bristol: Hefce

24. Keith A., (2006) in Kouzes, J., and Posner, B. (2007). The Leadership Challenge. CA: Jossey Bass

25. Kouzes, J.M., and Posner, B.Z. 2002,. The Leadership Challenge: How to Get Extraordinary Things Done in Organizations. San Francisco: Jossey-Bass.

26. LaBo. T.P. (2005). Relationship Between Leader-Member-Exchanges and Emotional Intelligence in Public Schools: A Regressional Approach. ProQuest Informantion Learning Co. Ann Arbor.

27. Lambert, S.J. (2006). Both art and science: Employing organizational documentation in workplacebased research. In Pitt-Catsouphes, M., Kossek, E.E., \& Sweet, S. (Eds.). The work and family handbook: Multi-disciplinary perspectives, methods, and approaches. (pp.503-525). Mahwah, New Jersey: Lawrence Erlbaum Associates.

28. Lee, K., \& Allen, N. J. (2002). Organizational citizenship behaviour and workplace deviance: The role of affect and cognitions. Journal of Applied Psychology, 87(1), 131-142.

29. Leveille, D. (2006), Accountability in Higher Education: A Public agenda for Trust and Cultural Change, Centre for Studie in Higher Education, CA - USA

30. Liden, R.C., Sparrowe, R.T., Wayne, S.J. (1997). Leader-Member Exchange Theory. The past and Potential for the Future. In Research in Personnel and Human Resources Management by Gerald Ferris (Ed). Jai Press, Greenwich Ct. 47 -- 119

31. Liden, R.C., Maslyn, J.M. (1998). Multidimensionality of Leader-Member Exchange: An Empirical Assessment Through Scale Development. Journal of Management, 24 (1), 43-72.

32. Lim, J. Y., \& Cromartie, F. (2001). Transformational leadership, organizational culture and organizational effectiveness in sport organizations. The Sport Journal, 4(2), 111-169.

33. O’Neill M, (2003), Ergonomic Design for Organizational Effectiveness, 61-65

34. Organ, D. W. (1997). Organizational citizenship behavior: It's construct cleanup time. Human Performance, 10(2), 85-97.

35. Organ, D. W., Podsakoff, P. M., \& MacKenzie S. P. (2006). Organizational citizenship behavior: Its nature, antecedents, and consequences. London: Sage Publications.

36. Organ, D. W. (1988). Organizational citizenship behavior: The good soldier syndrome. Lexington, MA: Lexington Books.

37. Podsakoff, P. M., Ahearne, M., \&MacKenzie, S. B. (1997). Organizational citizenship behavior and the quantity and quality of work group performance. Journal of Applied Psychology, 82, 262-270.

38. Rost, J.C. (November, 1993). "Leadership Development in the New Millennium." The Journal of Leadership Studies: 91-110.

39. Schnake, M. (1991). Organizational citizenship: A review, proposed model, and research agenda. Human Relations, 44, 735-759. 
40. Shattock, M. (2003). Managing Successful Universities. Buckingham: SRHE and OU Press.

41. Shriberg, A.J., \& Shriberg, D. (2005). Practicing leadership: It's your turn. . In A.J. Shriberg, D. Shriberg, \& R. Kumari (Eds.), Practicing leadership: Principles and applications (3rd ed., pp. 264-273). New York: Wiley.

42. Smith, C. A., Organ, D. W., \& Near, J. P. (1983). Organizational citizenship behavior: Its nature and antecedents. Journal of Applied Psychology, 68, 653-663.

43. Smith, M. K (2008) 'What is a group?', the encyclopaedia of informal education. www.infed.org/groupwork/what_is_a_group.htm

44. Stoltz, Paul G (2000) Adversity quotient at work: Make everyday challenge the key to your success-putting principles of $A Q$ into action. N.Y.: HarperCollins Publishing, Inc

45. Stoltz, P. G \& Weihenmayer, E. (2006). The adversity advantage: turning everyday struggles into everyday greatness. New York: Simon \& Schuster

46. Trukenbrodt Y.(2000) Relationship between Leader-Member Exchanges, Committment and Organizational Citizenship behaviour, Acquisition Quarterly

47. Watz, D., \& Shaffer, M. A. (2005). Equity and relationship quality influences on organizational citizenship behaviors: The mediating role of trust in the supervisor and empowerment. Personnel Review, 34, 406-422.

48. Weese, W. J. (1996). Do leadership and organizational culture really matter? Journal of Sport Management, 10(2), 197-206.

49. Zaccaro, S. J., \& Klimoski, R. J. (2001). The nature of organizational leadership: An introduction. In S. J. Zaccaro \& R. J. Klimoski (Eds.), The nature of organizational leadership: Understanding the performance imperatives confronting today's leaders (pp. 3-41). San Francisco, CA: Jossey-Bass. 